\title{
The bidirectional capacity of bacterial antigens to modulate allergy and asthma
}

\author{
H. Renz, U. Herz
}

The bidirectional capacity of bacterial antigens to modulate allergy and asthma. H. Renz, U. Herz. C) ERS Journals Ltd 2002.

ABSTRACT: In recent decades, the prevalence of allergic diseases including bronchial asthma, hay fever and atopic dermatitis, has risen steadily in high-income countries. The underlying mechanisms for this phenomenon remain largely unknown. Since the natural mutation rate is low, altered environmental and lifestyle conditions are thought to play an important role.

Epidemiological and clinical studies have provided indirect evidence that infections may prevent the development of atopy and atopic disease. This is referred to as the "hygiene hypothesis". According to the hygiene hypothesis, viral and/or bacterial infections could inhibit the T-helper (Th)-2 immune response associated with atopic reactions by stimulating a Th- 1 response involved in defence of bacterial infections and delayed-type hypersensitivity reactions.

In particular, the prenatal period and early childhood are considered to be critical for the establishment and maintenance of a normal Th-1/Th-2 balance. On the other hand, several studies suggested that infections exacerbate established allergic diseases, e.g. bronchial asthma, airway hyperresponsiveness and atopic dermatitis. Therefore, viral and/or microbial infections and/or their products may have bidirectional effects on the development of allergy and asthma.

This review will focus on recent findings related to the interaction between allergic disorders and infectious diseases, with the main emphasis on bacterial infections. Eur Respir J 2002; 19: 158-171.
Dept of Clinical Chemisty and Molecular Diagnostics,

Philipps University Marburg,

Germany.

\section{Correspondence: H. Renz}

Central Laboratory

Hospital of the Philipps University

Baldingerstr.

D-35033 Marburg

Germany

Fax: 4964212865594

Keywords: Allergy

asthma

atopy

bacterial antigens

T-helper 1/T-helper 2 balance

Received: March 202001

Accepted after revision June 192001
It is well established that allergy and asthma result from a complex interaction between genetic and environmental factors. Although there is no doubt that genetic polymorphisms at multiple sites in the genome contribute to the predisposition for the development of these conditions, the immediate environment also plays a crucial role in determining the time of onset, maintenance and severity of allergy and asthma. The contribution of the environment is underscored by the overwhelming evidence regarding the dramatic rise in allergy and asthma prevalence and incidence particularly in high-income countries around the world [1,2]. Numerous studies have shown a several fold increase in allergic diseases during the last few decades. This increase cannot solely be explained by genetic factors since the natural mutation rate is low and substantial shifts in the genome do not occur over a few generations. Therefore, research has recently focused on the identification and isolation of environmental factors which contribute to this phenomenon. More recently, the so called "hygiene hypothesis" has been put forward to explain the epidemiological data $[3,4]$.

Allergy and asthma are associated with a profound immunological deregulation characterized by an overproduction of T-helper (Th)-2 T-cells. It is well established that Th-2 effector function is negatively regulated by Th-1 T-cells. Th-1 cells seem to play a critical role in defence against various microbial antigens including bacterial, viral and fungal infections. The hygenie hypothesis suggests that a reduced frequency of infections, less severe infection and prevention of infection by e.g. frequent use of antibiotics would prevent maturation of Th-1 immunity and, therefore, would give rise to a allergen-specific Th-2 immune response following natural exposure to allergens.

It is the purpose of this review to discuss the

Previous articles in this series: No. 1: von Mutius E. Infection: friend or foe in the development of atopy and asthma? The epidemiological evidence. Eur Respir J 2001; 18: 872-881. No. 2: Wennergren G, Kristjánsson S. Relationship between respiratory syncytial virus bronchiolitis and future obstructive airway diseases. Eur Respir $J$ 2001; 18: 1044-1058. 
evidence both in favour and against the hygiene hypothesis, focusing on bacterial infections and, to a lesser extent, on viral antigen exposure.

\section{The concept of T-helper 1, T-helper 2 and T-helper 3 immune deviation}

During the last two decades, the cellular and molecular mechanisms of allergic inflammation have been revealed to a large extent. A breakthrough in understanding the regulation of allergic immune responses came with the discovery of different $\mathrm{T}$-cell effector subsets termed T-helper (Th)-1 and Th-2 $[5,6]$. Both $\mathrm{T}$-cell subsets are characterized by a unique pattern of cytokine production. Th-1 cells produce interferon (IFN)- $\gamma$, interleukin (IL)-2 and tumour necrosis factor (TNF)- $\beta$. In contrast, Th-2 cells are defined by the exclusive production of IL-4, IL-5, IL-6, and IL-10 [5, 6] (fig. 1). Th-1 cells play an important role in host defence against a wide range of microbes including viral, bacterial, and fungal antigens, contribute to the production of immunoglobulin-(Ig)M and IgG antibodies, the formation of granuloma and the development of cytotoxic T-cell responses. Recently, the Th1/Th2 concept which was originally exclusively used to describe the CD4 T-cell subset was extended to include CD8 T-cells as well $[7,8]$. In contrast, Th-2 T-cells play a critical role in the defence of helminthic infections. This type of infection requires recruitment and activation of eosinophils as well as formation of $\operatorname{IgE}$ antibodies [9, 10].

Further studies have addressed the question whether deregulation in T-cell subset formation may play an important pathophysiological role in certain diseases. Since allergic diseases are characterized by

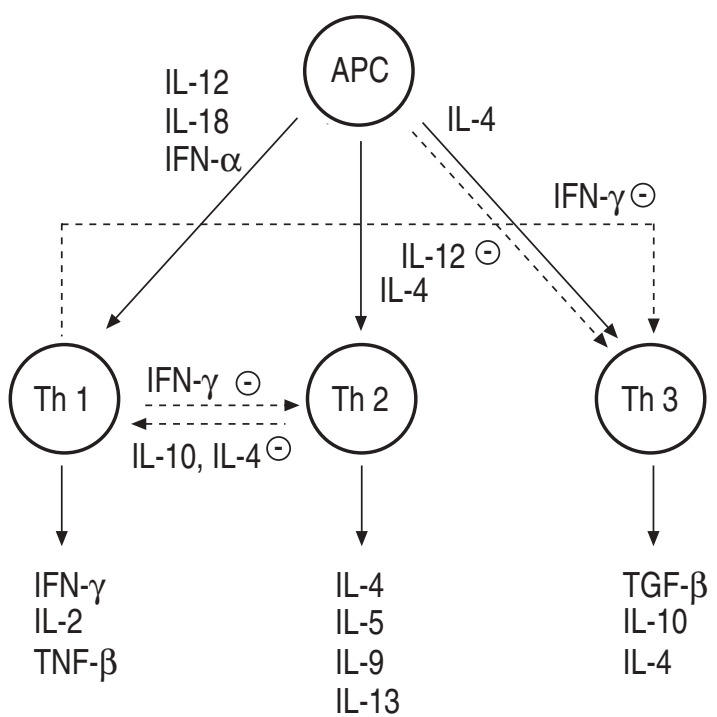

Fig. 1.-Positive and negative regulatory effects of cytokines in development and effector functions of T-helper (Th)-1, Th-2, and Th-3 T-cells. Positive effects: solid arrows; Negative effects: dashed arrows. APC: antigen presenting cell; IL: interleukin; IFN: interferon; TGF: transforming growth factor; TNF: tumour necrosis factor. production of $\operatorname{IgE}$ and local recruitment of eosinophils, it was no surprise that extensive investigations carried out in patients suffering from respiratory and skin allergies revealed the importance of the Th-2 T-cell subset in allergic inflammation. These cells control regulation of IgE production via IL-4 and IL-13 release. Furthermore, certain aspects of eosinophil and mast cell biology are also closely monitored by Th- 2 cells including maturation, recruitment, and activation. In addition, IL-5 represents an important survival factor for the eosinophils via prevention of apoptosis [11, 12].

Recently, a third T-cell subset has been discovered termed Th-3 (fig. 1). This T-cell subset is defined by the production of transforming growth factor (TGF)$\beta$ in addition to IL-4 and IL-10 [13-15]. The TGF- $\beta$ superfamily consists of a number of structurally related regulatory proteins which include besides TGF- $\beta_{1}-$ TGF $-\beta_{5}$ the inhibins, activins, bone morphogenic and related morphogenic proteins, all of which are of significant importance in many areas of cell biology [16]. The five isoforms of TGF- $\beta$ share biological activities. The prototype of this family is TGF- $\beta_{1}$ a cytokine that was originally purified from human platelets. Interestingly, human platelets represent the most concentrated natural source of TGF- $\beta$ [17]. In mammalian species only TGF- $\beta_{1}, \mathrm{TGF}-\beta_{2}$, and TGF- $\beta_{3}$ have been identified and cloned.

TFG- $\beta$ is produced by every cell lineage and exhibits a wide variety of partially antagonistic and diverse functions (table 1) [16]. TGF- $\beta$ plays an important role in immune activation (upregulation of adhesion molecules, enhanced chemotaxis and enhanced production of $\operatorname{IgA}$ ) as well as in immune deactivation. Under certain conditions, TGF- $\beta$ inhibits proliferation of CD4 as well as CD8 T-cells, down-regulates several B-cell functions, including immunoglobulin production, and natural killer (NK)cell activities [18-24]. Furthermore, cytotoxic T-cells are also downregulated in the presence of TGF- $\beta$. Resolution of inflammation, particularly during chronic inflammation, results in fibrogenesis and angiogenesis. Both are also under close control of TGF- $\beta$. TGF- $\beta$ expression has been observed in mucosal tissues. The expression pattern in the mucosal tissues of the gut and nose initiated a number of investigations in the field of mucosal tolerance. There

Table 1.-Transforming growth factor- $\beta$ and immune responses

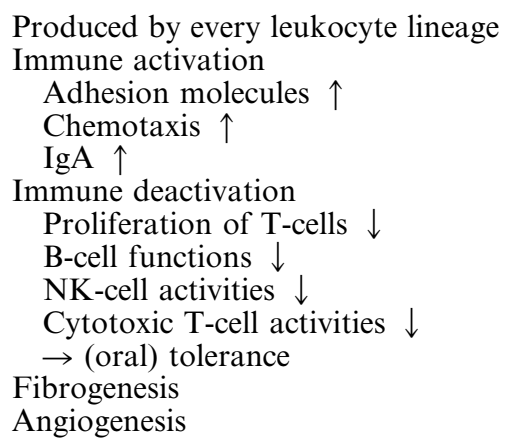

IgA: immunoglobulin-A; NK-cell: natural killer cell. 
is ample evidence that particularly on the mucosal site TGF- $\beta$ is directly involved in the regulation and maintenance of oral tolerance [25-27].

Formation and maintenance of T-cell effectors do not represent a static and fixed function of the immune system, but rather demonstrate a great extent of dynamic plasticity operating on several regulatory levels. Firstly, at the level of T-cell development, the development of T-cell effector subtypes depends on a number of signals and factors delivered both in a cognate as well as in a non-cognate fashion. Antigen-presenting cells phagocytose and process antigen and present antigenic peptides via major histocompatibility (MHC) class-II molecules. These antigenic peptides are bound to the MHC binding groove in the endoplasmic reticulum followed by transport to the cell surface. This complex of MHC plus peptide engages with the $\alpha / \beta$-T-cell receptor. In addition to this cognate signal, several noncognate signals have been identified which contribute to Th-subtype development (fig. 1). For example, the development of Th-1 T-cells is triggered by IL-12 and IFN- $\alpha$, whereas the development of Th-2 T-cells requires initial IL-4 [28]. However, cellular sources of this initial IL-4 have not been convincingly identified. Mast cells and basophils have been proposed as possible sources $[29,30]$. Most recently a novel concept has been put forward proposing that the dichotomy of T-cell effectors is also reflected on the level of antigen presenting cells. Most prominently KALINISKI et al. [32] have proposed the development of analogous types of dendritic cells (DC) termed DC-1 and DC-2 which promote the development of Th-1 versus $\mathrm{Th}-2$, respectively $[31,32]$.

The second level of plasticity is exhibited on the level of pre-existing Th-cell subsets (fig. 1). For example, the Th- 1 derived cytokine IFN- $\gamma$ is the most potent inhibitor of Th-2 immune cells, and vice versa IL-4, IL-10, and to a lesser extent TGF- $\beta$, suppress Th-1 T-cell functions. Furthermore, IL-12 and IFN- $\gamma$ have been shown to inhibit Th-3 effector T-cells. It is of great importance that naive T-cells are not preprogrammed to develop into either subset. However, the microenvironment at the site of antigen presenting cell (APC)/T-cell interaction is decisive for the development of these T-cell effectors. Once a single $\mathrm{T}$-cell has been fated for a certain Thphenotype, this decision is fixed. A redirection from one phenotype into another T-cell phenotype has not been shown so far on the single cell level.

How is the decision made about the development of $\mathrm{T}$-cell effectors, and what are the factors determining the outcome of the response? So far, individual components of the microenvironment have been identified which play a role in the development of certain T-cell effector phenotypes. They include: 1) type of APC (e.g. B-cells versus dendritic cells); 2) nature of the antigen; 3 ) dose of the antigen (low dose versus high dose); 4) site of antigen encounter (mucosal versus systemic); and 5) age of initial antigen priming (pre-, postnatal, adult) and others. This concept is of great practical importance for the development of naturally occurring immune responses. It implies that each time an antigen is delivered to T-cells a correct recognition and decision has to be made in terms of whether this is a harmful antigen or a harmless one and, as a consequence, which type of T-cell effector response represents the most appropriate answer.

\section{Concept: atopic infants start out as T-helper 1 weaklings}

The concept of Th-1, Th-2 immune deviation also applies to the situation of pregnancy. It has been revealed during the last few years that the foetomaternal interface represents an immunologically highly active site of regulation. Since foetal tissue is regarded as a classical allo-transplant expressing histocompatibility antigens (HLA) from father and mother, rejection of this allo-transplant must be avoided. The immune system has developed several strategies to prevent recognition of paternal HLA antigen, followed by subsequent development of cytotoxic T-cell responses against these cells. One major strategy to accomplish this relates to the Th-1/ Th-2 concept. Since it is the task of both CD4 and CD8 Th-1 T-cells to mediate transplant rejection, development of such dangerous T-cell responses must be suppressed. This is, at least, in part accomplished by the profound upregulation of cytokines belonging to the Th-2 and Th-3 phenotype. In fact, high level expression of IL-4, IL-10 and TGF- $\beta_{1}$ has been demonstrated at the foeto-maternal interface [33]. Both, foetal and maternal cells contribute to these regulatory events.

At the same time, development of the foetal immune system takes place and, at least, the T- and B-cell compartments are functionally set up around weeks 17 to 20 of pregnancy. These lymphocytes are then ready to encounter antigens and to develop into mature T-cell effectors. Evidence for this active immune maturation process has been provided by several investigators. It is now well accepted that antigen specific T-cells are present in cord blood (CB) $[34,35]$. These cells are indeed of foetal and rather than maternal origin. T-cell responses against nutritional antigens including casein, lactoglobolin, lactalbumin and ovalbumin as well as T-cell responses against harmless environmental antigens including house dust mite and certain pollen allergens have been demonstrated. Active intra-uterine development of the B-cell compartment is indicated by the presence of antigen-specific secretory $\operatorname{IgA}$ antibodies (sIgA) in newborns. Again cow's milk and hen's egg $\operatorname{sg} A$ antibodies have been detected [35].

Such T-cell maturation occurs intra-uterinally in a Th- 2 and Th-3 biased environment. This environment apparently has a marked impact on the development of Th-1 and Th-2 phenotypes in late foetal and early post-natal life.

Several studies indicate that the Th-1 capacity as assessed by the amount of IFN- $\gamma$ production is even further reduced in cases at risk, as compared to nonrisk neonates (table 2). The studies which address this issue differ in several major methodological aspects. WARNER et al. [36] and Kondo et al. [37] assessed 
Table 2. - T-helper (Th)-1/Th-2 imbalance at birth and development of atopy

\begin{tabular}{|c|c|c|c|c|}
\hline Cytokine & Stimulus & Outcome & Follow-up yrs & 1st author [ref no.] \\
\hline IFN- $\gamma \downarrow$ & Allergen & $\begin{array}{l}\text { Atopic eczema, skin } \\
\text { test reactivity }\end{array}$ & 1 & WARNER [36] \\
\hline IFN- $\gamma \downarrow$ & Mitogen & Skin test reactivity & 1 & TANG [38] \\
\hline $\begin{array}{l}\text { IFN- } \gamma \downarrow \\
\text { IL-2 } \downarrow\end{array}$ & Mitogen (at 9 months) & Skin test reactivity & 6 & MARTINEZ [39] \\
\hline $\begin{array}{l}\text { IL-4/IL-5 } \uparrow \\
\text { IFN- } \gamma=\end{array}$ & Allergen-TCC & Atopy & 3 & PICCINI [40] \\
\hline IFN- $\gamma$ & Allergen & Allergic disease & 6 & KONDO [37] \\
\hline Persistance of foetal Th2 $\uparrow$ Th1 $\downarrow$ & Allergen & Atopy & 2 & PRESCOTT $[35,41]$ \\
\hline
\end{tabular}

IFN: interferon; IL: interleukin; TCC: T-cell clones.

cytokine production in allergen stimulated CB mononuclear cells and followed infants for up to one year and six years, respectively. Outcome parameters were atopic eczema and skin test reactivity. In contrast, TANG et al. [38] and MARTINEZ et al. [39] employed mitogen stimulation of CB-cells and followed their cohort for one and six years, respectively. The cytokine pattern of allergen specific T-cell clones was assessed in the study by PICCINNI et al. [40] who reported a follow-up period of three years. PRESCOTT and co-workers $[35,41]$ studied allergen specific T-cell responses and provided a thorough follow-up for two years. They determined cytokine production on both transcriptional and translational levels. Regardless of whether CB-cells were stimulated with allergen or mitogen, a further reduced capacity to produce IFN- $\gamma$ in each case has been noted as compared to nonrisk controls. Although the data are quite consistent with respect to suppressed Th-1 immunity, the pattern of Th-2 immunity is still a matter of debate. In most studies Th-2 cytokine production has not been investigated with the exception of the studies by PRESCOTT and co-workers [35, 41]. These reports provide initial evidence that reduced IFN- $\gamma$ production might be associated with enhanced and even persistently elevated Th-2 cytokines production in such infants. However, it is important to note that the size of the cohorts was small and the period of followup was rather short. Further longitudinal studies need to be conducted with well defined cohorts in order to accumulate sufficient data allowing prospective immunomodulatory strategies with the aim of readjusting the Th1/Th2 balance in infants at risk.

The first experimental evidence that maternal sensitization favours the development of allergy in offspring was obtained from animal studies (fig. 2). These studies showed that offspring from normal healthy mice were characterized by impaired IFN- $\gamma$ production at birth which was even further lowered in offspring from allergen-sensitized mothers. After exposure to a heterologous allergen, the offspring derived from allergen-sensitized mice developed an accelerated Th-2-driven immune response compared to offspring from nonsensitized mice [42]. These data suggest that $\mathrm{Th}-2 / \mathrm{Th}-0$ immunity present during pregnancy has a decisive impact on shaping the Th$1 / \mathrm{Th}-2 \mathrm{~T}$-cell profile in response to post-natal allergen exposure.

A reliable biomarker to assess the presence of Th-1

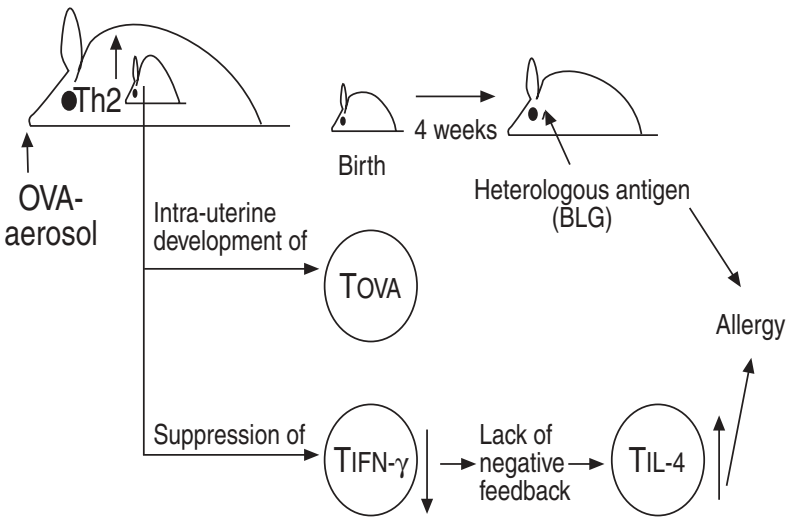

Fig. 2.-Maternal T-helper (Th)-2 immunity affects pre- and postnatal immune responses in an antigen-dependent and independent fashion. Th: T-helper cell; BLG: beta-lactoglobulin; OVA: ovalbumin; IL-4: interleukin-4; IFN- $\gamma$ : interferon-gamma; TovA: ova-specific T-cell; TIL-4: IL-4 producing T-cell; TIFN- $\gamma$ : IFNgamma producing T-cell. Arrows indicate increase or decrease of production.

immunity on the level of antigen-specific responses is the development of delayed type hypersensitivity (DTH) responses. It is a well known phenomenon that, for example, infants with atopic dermatitis express suppressed responses to recall antigens in this test. This test cannot only be performed in vivo, but also in vitro by assessing lympho-proliferative responses to antigens. The useful prototypic antigen in this regard is the proliferative response to tetanus toxoid (TT) following dipheria-pertussis-tetanus (DPT) vaccination. Recently PRESCOTT et al. [43] published an elegant study in which lympho-proliferative responses to TT were assessed in 2-yr-old infants following DPT vaccination. The response pattern was correlated with the level of serum IgE. They found several fold higher levels of serum IgE in those infants exhibiting a lack of lympho-proliferative responses. In contrast, infants with a positive response to TT following DPT vaccination had reduced levels of serum IgE [43]. Again, this observation further underscores the inverse relationship between Th-1 immunity (as assessed by the presence of DTH responses) and Th-2 immunity (as assessed by serum IgE antibody levels). However, the question concerning the causal relationship between these two events remains open. Whether the incapacity to mount appropriate Th-1 
immune responses allows the uncontrolled development of Th-2 immunity, or whether infants with already elevated Th-2 immunity have an incapacity to mount appropriate DTH responses remains to be studied.

\section{Relationship between infections and development/ exacerbation of allergy and asthma}

In numerous studies during the last decades, an inverse relationship between asthma and the overall burden of respiratory infections has been reported. These studies are summarized in table 3. Although these studies relate to an interesting concept, the cause-effect relationship regarding the impact of viral infections on the prevention/suppression of allergy and asthma still remains an open issue.

There is no doubt that common colds are the most frequent cause of asthma exacerbation in both children and adults [58-62]. The underlying mechanisms have been extensively analysed and reviewed [63]. One mode of action might be an additive effect of airway inflammation resulting from the inflammatory response to viral infections in an already inflamed mucosal tissue. Several studies have found an increased incidence of asthma in children with a history of childhood bronchiolitis [51-53, 56, 57, 64-70]. Virus infected patients with asthma have enhanced cytokine responses, apparently leading to prolonged lymphocytic and eosinophilic accumulation in the tissue [71]. One of the major causes of early childhood bronchiolitis is respiratory syncytial virus infection, which will be extensively discussed by SCHWARZE and GELFAND [72] in this series.

The data from these studies and further experimental studies (discussed later) suggest that the timing between infection and allergen exposure may be of great importance in terms of the immunological consequences. In the case of a wide gap between infection and allergen exposure, infections may have a protective effect. In contrast, a closely timed relationship between infection and allergen exposure and infection of already allergic/asthmatic patients may have a disease aggravating effect. Although the evidence supporting the concept of asthma exacerbation in relationship to viral infections is relatively strong, the association of bacterial respiratory infections with exacerbations of wheezing remains relatively weak. An exception is the association between chronic sinusitis and asthmatic symptoms. The data linking infection of the para-nasal sinuses to asthma are mainly associative and have been reported by several investigators [73-78]. However, causality has been difficult to prove. The mechanisms by which infection of the sinuses may contribute to acute exacerbation of asthma are known, but may include bacterial seeding from the upper to lower respiratory tract (the post-nasal trip theory), naso-sino-bronchial reflex or infection-induced enhancement of $\beta$-adrenergic blockade.

\section{The issue of mycobacterial infection and Bacillus Calmette-Guérin (BCG) vaccination}

The relationship between mycobacterial infection and Bacillus Calmette-Guérin (BCG) vaccination represents another model situation to assess the relationship between Th-1 and Th-2 immunity. Bacterial infections with, for example, Bordetella pertussis, Listeria monozytogenes, Mycobacterium bovis, leishmania and many others are associated with increased production of IFN- $\gamma$, reflecting the requirement of Th-1 immunity for defence and protection [79-82]. Cytokines produced by the cells of the innate immune system including macrophages and NK cells in response to Mycobacterium tuberculosis and/or its components, were able to shift, at least in vitro, the development of allergen-specific T-cells from a Th-2/ Th- 0 to a Th-1 profile. These cytokines include IL-12 and IFN- $\alpha$ which play an important role in the development of Th-1 effector cells.

One of the first studies which addressed this issue, employing a cross-sectional epidemiological approach, was published by ShiraKawa et al. [59]. The authors reported that among BCG immunized Japanese school children, asthmatic symptoms and several other index factors of atopy, were significantly less likely in positive tuberculin responders compared to

Table 3. - Inverse relationship between viral infections/immunizations and respiratory allergy, clinical and epidemiological data

\begin{tabular}{lll}
\hline Subject of paper & Country & 1st author [ref no.] \\
\hline Jaundice/HAV and asthma (1 case; 3 cases) & & BOROS [44] \\
Respiratory infections and asthma & GORIN [45] & MANTLE [46] \\
& Tristan da Cunha & TYRELL [47] \\
& & SAMUELL [48] \\
& BROWN [49, 50] \\
Respiratory infections and asthma & Western Carolinas & ANDERSON [51] \\
& Fiji Guinea & FLYNN [52, 53] \\
Respiratory infections and allergy/asthma/BHR & East/West Germany & VON MUTIUS [54] \\
Chicken pox and asthma/rhinitis (3 cases) & Italy & SERAFINI [55] \\
Measle infection and atopy (mortality 25\%) & Guinea Bissau & SHAHEEN [56] \\
HAV infection and clinical allergy & Italy & MATRICARDI [57] \\
\hline
\end{tabular}

HAV: hepatitis A virus; BHR: bronchial hyperresponsiveness. 
negative responders, and that remission of atopic symptoms between the ages of seven and 12 years was much more likely in positive tuberculin responders. The interpretation of these findings has been debated intensively. It is of importance that all infants enrolled in this study have undergone an extensive BCG vaccination schedule. At the age of six years tuberculin nonresponders have been revaccinated. The most likely interpretation of these results is that the inverse association between the atopic status and DTH responses may simply reflect the imbalance of Th-1/Th-2 responsiveness. It is the failure to respond appropriately after BCG vaccination that is associated with the development of atopic symptoms rather than the BCG vaccination per se. Such an interpretation is further supported by the findings of Swedish investigators, again indicating that a single immunization for BCG after birth does not affect the prevalence of atopic diseases at school age [83, 84].

In recent studies, however, an inverse relationship between BCG vaccination and atopy, as defined by skin-test reactivity to common allergens, has been reported in Guinea Bissau [85]. However, in that study the BCG response pattern has not been assessed. In contrast, a study performed on unselected children in Sweden found no reduction in atopic diseases associated with BCG in infancy amongst children born in Sweden [84]. In contrast, among immigrant children, many born in Asia and South America, BCG was associated with a lower prevalence of atopic diseases [86]. This interesting observation may point to differences among ethnic groups.

It is important to distinguish between BCG vaccination and mycobacterial infection. Recently, vON Mutius et al. [87] reported a significant inverse correlation between the prevalence of asthma and reported rates of tuberculosis. To further explore underlying mechanisms of this epidemiological phenomenon animal model systems have been employed by several investigators [88-90]. In one such model IgE-high responder BALB/c mice were infected with a $B C G$ vaccine prior to sensitization against ovalbumin. It is important to note that the BCG vaccine contains attenuated mycobacteria which results in severe generalized mycobacterial infection in such animals. Therefore, this reflects a model situation of generalized infection with a facultative intracellular organism. It was shown that such an infection prior to allergic sensitization prevented the development of $\mathrm{IgE} / \mathrm{IgG} 1$ antibody responses, immediate positive-type skin-test responses and airway hyperresponsiveness together with prevention of allergic airway inflammation. In parallel, a marked rise in antiovalbumin specific IgG2a antibodies was found, reflecting the development of an OVA-specific Th-1 instead of Th-2 response [88]. A further study revealed that this effect was mediated via IFN- $\gamma$ since the protective effect of mycobacterial infection was lost in IFN- $\gamma$ receptor knock-out mice [89]. However, the exact mechanism of how IFN- $\gamma$ mediates this effect is not yet clear. Interestingly, it appears that bacteria do not necessarily have to be alive in order to prevent allergic responses since killed Listeria monozytogenes,
Mycobacterium vacae or Lactobacillus plantarum could also suppress allergic responses in mice [80, 91].

\section{Bacterial components: deoxyribonucleic acid}

It is of major interest to identify and characterize bacterial components which are able to influence the Th-1/Th-2 balance. In this context, bacterial deoxyribonucleic acid (DNA) has been shown to exert a dramatic effect on the immune system [92]. Bacterial (but not mammalian) DNA has mitogenic properties for a number of cells of both the innate and adaptive immune system. These properties are due to unmethylated "CpG motifs" containing oligodeoxynucleotides (ODN) [93, 94]. The key CpG motif influencing human immune responses is defined by the GACGTT sequence and in the mouse by GTCGTT. The phosphorothionate backbone seems to be an essential prerequisite of $\mathrm{CpG}-\mathrm{ODNs}$ to exhibit their immunomodulatory properties.

The immunogenicity of such CpG-ODNs has been extensively studied, particularly in the murine system [95-99]. They directly interact with certain subsets of APC including DC subpopulations, NK and B-cells [100]. The activation of DC by CpG-ODN results in increased expression levels of costimulatory molecules and an increase in antigen presentation and priming $[101,102]$. Within a few hours, several chenokines and cytokines are being expressed, especially IL-12, IFN- $\alpha$ and TNF- $\alpha$, all of them playing an important role in Th-1 promotion. Monocytes and macrophages exhibiting increased antibody-dependent cellular cytotoxicity. IL-12, TNF- $\alpha$ and IFN- $\alpha$ have direct effects on NK cell activity [103]. They induce IFN- $\gamma$ and increase the cytolytic activity of NK cells. To a lesser extend, CpG-ODN also affect B-cell activities [104]. B-cells rapidly produce IL-6 and IL-10 and express increased levels of costimulatory molecules [105]. Although T-cells are not directly activated by $\mathrm{CpG}-\mathrm{ODN}$, their response and activation pattern is indirectly affected via the enhanced response profile on APC. Thus, development of Th-1 effector cells on both the level of CD4 and CD8 T-cell subsets is a major result of exposure to CpG-ODN [106].

The therapeutic potential of bacteria and bacterial extracts in the treatment of particularly malignant disease has been known for more than a hundred years. In this respect, BCG extracts have been studied to a great extent. About sixty years ago, Freund's adjuvant, consisting of mycobacterial extract in oil immersion, was characterized as an immunomodulator with similar therapeutic activities. Defined as complete Freund's adjuvant this is one of the most potent modalities for generation of Th-1 immune responses. Yet, it was not until 1984 that ToKunAGA et al. [107] found that it was the mycobacterial genomic-DNA activation of NK cells that was responsible for the potent anti-tumour activity of BCG [107]. This observation stimulated further research on the immunogenicity of bacterial DNA [108-111]. The potent immunological response suggests that bacterial DNA serves as an evolutionary conserved lesion for the vertebrate immune system 
which recognizes this structural pattern as a danger signal. More recently, synthetic ODNs containing immunostimulatory DNA sequences have been identified to exhibit adjuvant activity and to induce Th-1 like immune responses.

In addition to their anti-tumour and cytotoxic activity, Th-1 cells play an important role as immunoregulators by direct Th-2 inhibiting effects. Based on this capacity, it has recently been explored whether CpG-ODNs have antiallergic effects. This preventive and/or therapeutic potential has been extensively analysed, particularly using murine models of allergy and asthma [112]. It has been shown that only one injection or mucosal administration of CpG-ODNs given before the allergen challenge to sensitized mice inhibited lung and blood eosinophilia better than dexamethasone [113]. Levels of IL-3 and IL-5 and airway hyperreactivity were also reduced whereas IFN- $\gamma$ levels were increased. This phenomenon of immediate inhibition of the allergic response has been recently confirmed in another model of ragweed sensitization [114]. In that study it has been shown that the long-term Th-1 diversion of the allergenspecific response is stable for at least six weeks. This therapeutic potential of CpG-ODNs has been further explored in a well established animal model system of major birch pollen allergen which resembled a clinically highly relevant allergen model [115]. Coadministration of $\mathrm{CpG}-\mathrm{ODN}$ with birch pollen allergen in aluminium hydroxide resulted in markedly increased Th- 1 activities, resulting in markedly elevated $\mathrm{IgG} 2 \mathrm{a}$ levels and subsequently reduced airway inflammation. Furthermore, systemic or local/mucosal application of CpG-ODNs after aerosol sensitization also induced this Th-1 dependent antibody profile. The authors conclude that such CpG-ODNs as adjuvants may have an important impact on new forms of specific immunotherapy in allergic disease. In this context, particularly the mucosal route of application might have further potential. Although both prophylactic and therapeutic effects have been clearly demonstrated in several animal model systems, further research is needed to analyse possible long-term and side-effects and its efficiency in man.

\section{Bacterial components: lipopolysaccharides}

Several cross-sectional and longitudinal epidemiological studies have revealed a reduction in allergen sensitization and atopic diseases in children of farmers, children with pigs, dogs, or cats in their homes, children raised in day-care centres from an early age, and children of large families [116-120].

An interesting "human model" that may provide further insight in this context is the recent observation reported by several authors that growing up on farms confers significant protection against the development of atopy. This has been clearly demonstrated in a Swiss population study of school children aged 6-15 yrs [121]. Similarly in a large survey of Bavarian children entering school at ages 5-7 yrs old, the prevalence of hay fever among children raised on a farm was significantly lower than among their peers from the same villages who did not grow up on a farm [122]. Furthermore, a recent Austrian survey of children aged $8-10$ yrs has confirmed these findings [123]. Interestingly, the development of atopic eczema was not effected by the farming activities of the parents.

What is the nature of the environmental factor present on farms which confers protection against allergy and asthma? The living conditions of farming families differ in many respects from the lifestyles of other families and include a larger family size, more pets, frequently heating with wood or coal, less maternal smoking, more dampness and unique dietary habits. In the study cited above none of these factors could so far explain the effect. In contrast, contact with livestock and poultry was found to explain much of the relationship between farming and atopy.

In all these environmental settings gram-negative bacteria and their cell-wall component endotoxin (lipopolysaccharide (LPS)) may exist in abundance. Indeed, occupational disease studies have reported high levels of endotoxin exposure in farm settings $[124,125]$. Since bacterial endotoxin is known to induce IFN- $\gamma$ and IL-12 production, the hypothesis has been generated that chronic endotoxin exposure during early childhood and infancy may protect against the development of allergy and asthma.

This hypothesis was the basis for two recently published studies which aimed to compare indoor exposure to endotoxin and house dust with allergen sensitization in infants at high risk for developing asthma and/or wheezing. GEREDA et al. [126] measured concentrations of house dust endotoxin and allergens in the homes of 61 infants, aged 9-24 months, with at least three physician documented episodes of wheezing. In parallel, skin-prick testing with a panel of common inhalant and food allergens was carried out and the cytokines reflecting Th-1 and Th- 2 activities were measured. The homes of allergen-sensitized infants contained significantly lower concentrations of house dust endotoxin than those of nonsensitized infants. Increased house dust endotoxin concentrations correlated with increased proportions of IFN- $\gamma$ producing CD4 T-cells.

However, another recent study did not confirm this association. PARK et al. [127] examined the associations of house dust endotoxin, measured within the first three months after birth, with wheezing during the first year of life in a cohort of 499 children with one or both parents having a history of asthma or allergy. Their results suggest that endotoxin is associated with an increased risk of wheezing, and may promote persistent wheezing during the first year of life among children with a history of allergy or asthma. This occurred independent of the effect of lower respiratory infections, one of the strongest risk factor for wheezing in infancy. The association between early childhood infections and subsequent development of asthma were elegantly assessed in a birth cohort study by ILLi et al. [120]. The most important conclusion from this study was that the risk of asthma by age seven is reduced by $\sim 50 \%$ in children with two or more reported episodes of common colds during the first year of life. In contrast, children with 
wheezy lower respiratory illnesses in the first year of life tend to wheeze later on.

LPS serves as a potent inducer of cytokinefavouring Th-1 T-cell development. One mechanism through which LPS mediates this effect is by binding together with the LPS binding protein to the LPS receptor, CD14, which is expressed on a variety of APC, particularly monocytes and macrophages. Polymorphisms in the $5^{\prime}$ linking region of a CD14 gene have recently been identified and were associated with the intensity of atopy [128].

These data from cross-sectional studies provide circumstantial evidence suggesting a protective role for LPS in the development of allergic disease. However, the underlying molecular and cellular mechanisms are still unknown and need to be assessed.

It needs to be emphasized that the immunological consequences of LPS-exposure depend on a variety of conditions. It would be an oversimplification to conclude that in all cases LPS-exposure protects against allergy and asthma. The source and route of exposure to LPS may also be of importance since LPS is produced by several bacterial pathogenes (e.g. Haemophilus and Salmonella spp.) and comensales colonizing the gut (e.g. Escherischia coli). In this context it has been reported that the colonization of the gastrointestinal tract from newborn babies who had Lactobacillus and Eubacteria spp. (compared with those who had Clustridium difficile) correlated with a decrease in atopic disorders later in life [129]. Furthermore, it is well known that long-term high-dose exposure to LPS triggers a variety of adaptation processes which result in macrophage "desensitization".

Animal model systems offer the opportunity to assess the immunobiological effects of LPS on allergy and asthma. In this regard, it is now clear that the sequence of events determines the outcome. When LPS exposure occurred before allergen sensitization/ challenge, a preventive effect of LPS has been documented. In this regard intravenous LPS reduced antigen-induced bronchoconstriction in the guinea pig, and exposure early in sensitization prevented allergic sensitization in rats [130, 131].

In contrast, when LPS exposure occurred in already allergen-sensitized animals, LPS promoted the inflammatory response (fig. 3). This has been shown in several studies including a more recent investigation indicating that exposure to LPS in sensitized rats exacerbated the allergic immune response [131, 132]. To further complicate this issue, it has been also documented that intratracheal LPS induced bronchial hyperresponsiveness to serotonin and acetylcholine in the guinea pig even in the absence of allergen exposure and/or sensitization.

In conclusion, there is now circumstantial evidence suggesting that continuous LPS exposure in early life may have a preventive effect on allergy and asthma. This situation is closely reflected by the results in animal model system where LPS exposure prior to allergen sensitization has a well-documented preventive effect. In contrast, LPS exposure at a later stage, when allergen sensitization has already been established, may exacerbate and promote the inflammatory response. These experimental data may explain the 1st LPS $\longrightarrow$ 2nd Allergen

LPS i.v. reduced $A G$-induced bronchoconstriction in guinea pigs

VANNIER et al., 1991 [130]

\section{Low-dose LPS in BALF after allergen challenge amplifies inflammatory response DuBIN et al., 1996 [133]}

\section{LPS augmented $\lg E$} mice

SLATER et al., 1998 [132]

Exposure early in sensitization prevented allergic sensitization in rats TULIC et al., 2000 [131]

Exposure to LPS in sensitized rats exacerbated the allergic immune response

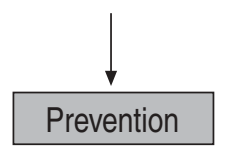
TULIC et al., 2000 [131]

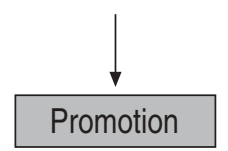
response to latex allergen in

Fig. 3.-Modifications of allergy and asthma by lipopolysaccharides (LPS). BALF: bronchoalveolar lavage fluid.

clinical observation of asthma exacerbation during bacterial and viral infection. Furthermore, these biological effects also depend on the route of exposure since intestinal LPS exposure may have a different effect.

\section{Bacterial components: superantigens}

Just as gram-negative bacteria secrete LPS as a major immunomodulatory component, gram-positive bacteria provide, via secretion of bacterial superantigens (enterotoxins), a major immunomodulatory stimulus (fig. 4). Bacterial superantigens act via a set of biological properties differing distinctly from conventional antigens. In contrast to conventional antigens which require uptake by APC, intracellular processing, presentation on MHC-class II molecules and recognition of the $\mathrm{MHC}$-class II plus peptide complex by the T-cell receptor, bacterial superantigens function differentially. They bind outside the conventional T-cell epitope-binding-groove on MHCclass II molecules and crosslink the MHC-class II molecule with the T-cell receptor $\mathrm{V} \beta$ chain. In the case of a conventional antigen, this mode of APC cell interaction results in the stimulation of $<0.1 \%$ of naive T-cells. In contrast, bacterial superantigens which recognize a defined set of T-cell receptor V $\beta$ elements, stimulate up to $25 \%$ of naive T-cells. Such interaction results in vigorous $\mathrm{T}$-cell activation and cytokine release, usually followed by deletion and apoptosis of the majority of T-cells.

One major source of such bacterial superantigens is $S$. aureus. In the case of atopic dermatitis, chronic colonization of the skin with toxin-producing $S$. aureus strains has already been well established. In a recent cross-sectional study $\sim 80 \%$ of children with atopic dermatitis (AD) show chronic colonization of the skin with $S$. aureus and $>50 \%$ of these children 


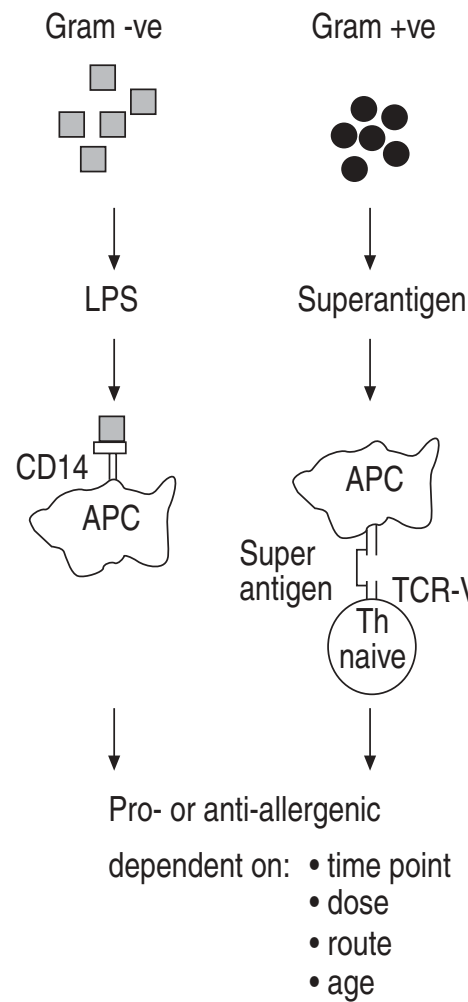

Fig. 4.-Bacterial toxins and their putative role in allergy and asthma. LPS: lipopolysaccharide; APC: antigen presenting cell; Th: T-helper cell; TCR: T-cell receptor.

were colonized with toxin-positive strains [134]. It was then assessed whether colonization with toxin-positive or toxin-negative strain would have any correlation with clinical severity as assessed by SCORAD (severity scoring of AD). The results of this study revealed the most severe cases of atopic dermatitis in the patient group colonized with toxin producing $S$. aureus strains. These data resulted in the hypothesis that bacterial toxins have a major impact on clinical severity of atopic dermatitis.

To further explore this issue, the T-cell receptor $\mathrm{V} \beta$ repertoire of skin-infiltrating $\mathrm{T}$-cells has been correlated with the pattern of toxins produced by the individual S. aureus strains [135]. Preferential accumulation of superantigen-responsive T-cells was observed in patients with intense skin inflammation. Additional evidence for disease-modulating effect of superantigens has been provided by a study performed by STRICKLAND et al. [136]. The authors showed that, in vitro, superantigens have the capacity to activate and expand T-cells expressing specific T-cell receptor $\mathrm{V} \beta$ gene-segments and also to increase their skinhoming capacity via upregulation of this skin-homing receptor, cutaneous lymphocyte-associated antigen in vitro.

The disease-modulating effects of superantigens have also been extensively studied in the model of humanized severe combined immunodeficiency (SCID) mice [137]. SCID mice exhibit a severe immunodeficiency syndrome due to a defect in the antigen-receptor recombinase. Due to this deficiency, mature $\mathrm{T}$ - and B-cells are absent in these mice and they accept xenotransplants without rejection. Transfer of atopic peripheral blood mononuclear cells from house-dust mite sensitized patients results in the development of house-dust mite specific $\mathrm{T}$ - and B-cell responses following antigen booster in these mice. When such reconstituted SCID mice were epicutaneously challenged either with the superantigen staphylococcal enterotoxin B (SEB) or house-dust mite allergen or a combination of both, an inflammatory response developed in the dermis and epidermis similar to skin lesions of atopic dermatitis. Most severe lesions were observed when mice were treated with a combination of SEB and house-dust mite allergen. In a recent study, SEB has been applied on normal and atopic skin, resulting in an influx of T-cells into the skin, leading to the induction of atopic dermatitis-like skin lesions [138].

At least in atopic dermatitis, S. aureus-derived superantigens can also function in an alternative fashion. Specific IgE antibodies directed against staphylococcal enterotoxin A (SEA) or SEB were detectable in a subgroup of atopic dermatitis patients $[134,139]$. The presence of these superantigen-specific IgE antibodies strongly correlates with disease severity and levels of total IgE. These results lead to the conclusion that these proteins can also function as conventional allergens resulting in an allergen-specific $\mathrm{T}$ - and B-cell response. In patients chronically colonized with superantigens secreting $S$. aureus strains, these toxins can easily penetrate through the disturbed epidermal barrier resulting in direct binding to $\operatorname{IgE}$ antibodies which are present on the surface of dermal mast cells. Through this mechanism, mast cells are chronically activated to release pro-inflammatory mediators perpetuating the itch-scratch cycle in these patients.

On the other hand, it has also been demonstrated that such bacterial superantigens can prevent and inhibit allergic responses in the mouse. When mice are cutaneously treated with SEB prior to allergen challenges (ovalbumin), the ovalbumin-induced allergic response is prevented. Although in this model, superantigen treatment most likely resulted in marked activation of the appropriate T-cells followed by deletion of the cells, the underlying immunological mechanisms explaining how superantigens prevent the development of the allergic response have not been explored in depth.

\section{Conclusion}

It is well accepted that the inflammatory response in allergic disease is characterized by the presence of a Th-2 mediated response. IgE antibodies represent important effector molecules and eosinophils and mast cells are predominant effector cells of the immediate hypersensitivity response. In (genetically) susceptible individuals with a unique type of immune response a pattern is initiated following the allergen exposure. Since indoor and outdoor allergens are ubiquitous, once the immune response is shifted towards the Th-2 phenotype, a chronic process of 
immunoderegulation results. Apparently, this process can already start in the intra-uterine environment. Since many, but not all, microbial antigens trigger a Th-1 immune response as a normal defence mechanism, a hypothesis has been put forward proposing that a negative correlation exists between the pattern and frequency of microbial infections and the onset and severity of allergy and asthma.

This hypothesis is supported by epidemiological data, indicating an inverse association between frequency, pattern and type of infection and the prevalence of allergy and asthma. In patients, however, a direct cause-effect relationship has not been demonstrated so far.

Experimental in vitro systems and animal models have been employed to further analyse the impact of microbial antigens on the development of allergic immune responses. The analysis of the available literature on this issue allows the following conclusion. Firstly, particular bacterial antigens have a capacity to dramatically modulate the immune response pattern (fig. 5). This has been demonstrated in models of bacterial infections (e.g. mycobacterial infections and BCG) as well as in situations were bacterial components have been used (e.g. LPS, bacterial superantigens). Secondly, the same bacterial antigen can either promote or prevent the allergic immune response (fig. 6). The outcome is critically dependent on the timing between exposure to microbial antigens and allergen sensitization. When microbial antigens are given the chance to develop a Th-1 immune response in a naive individual before the allergen can mount a Th-2 mediated inflammatory response, the Th-1 immune response is prevented. In contrast, acute or chronic encounter of bacterial antigens in an already Th-2 inflammed tissue usually aggravates the allergic condition. Thirdly, from current knowledge, a single transient infection or vaccination is not sufficient to direct the immune response towards such a strong Th-1 pattern that this could prevent the development of allergy and asthma later in life. In contrast, only frequent and repeated exposure to a variety of microbial antigens may lead to a longlasting induction of Th-1 immunity which may, as a consequence, eventually prevent the development of

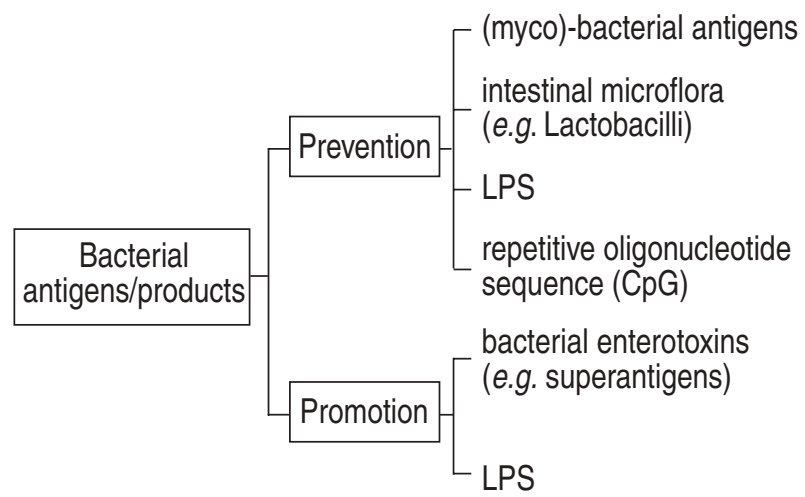

Fig. 5.-Bidirectional effect of bacterial antigens and their products in allergy and asthma. LPS: lipopolysaccharide.

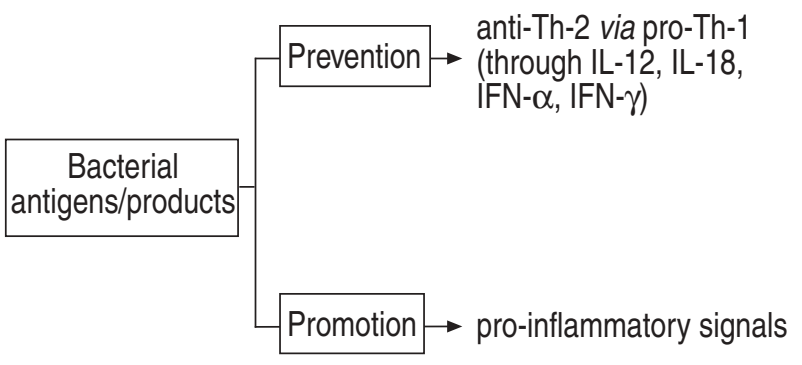

Fig. 6.-Prevention of allergy and asthma by microbial antigens; sequence of events and proposed mode of action. Th: T-helper cell; IL: interleukin; IFN: interferon.

Th-2 immunity and, therefore, may reduce the risk for the development of allergy and asthma.

This concept which is mainly based on experimental data, now requires testing in humans by the means of cohort and intervention studies. It needs to be explored how the immune system can be promoted to develop strong T-helper 1 immunity early in life. The experimental data further suggest that such an approach may only be useful if T-helper 1 immunity is installed before the immune system has the chance to mount a pathological T-helper 2 immune response against allergens in predisposed and susceptible individuals.

\section{References}

1. Worldwide variation in prevalence of symptoms of asthma, allergic rhinoconjunctivitis, and atopic eczema: ISAAC. The International Study of Asthma and Allergies in Childhood (ISAAC) Steering Committee. Lancet 1998; 351: 1225-1232.

2. Strachan D, Sibbald B, Weiland S, et al. Worldwide variations in prevalence of symptoms of allergic rhinoconjunctivitis in children: the International Study of Asthma and Allergies in Childhood (ISAAC). Pediatr Allergy Immunol 1997; 8: 161-176.

3. Strachan DP. Hay fever, hygiene, and household size. BMJ 1989; 299: 1259-1260.

4. Strachan DP, Harkins LS, Golding J. Sibship size and self-reported inhalant allergy among adult women. ALSPAC Study Team. Clin Exp Allergy 1997; 27: 151-155.

5. Mosmann TR, Cherwinski H, Bond MW, Giedlin MA, Coffman RL. Two types of murine helper T cell clone. I. Definition according to profiles of lymphokine activities and secreted proteins. J Immunol 1986; 136: 2348-2357.

6. Del Prete GF, De Carli M, Mastromauro C, et al. Purified protein derivative of Mycobacterium tuberculosis and excretory-secretory antigen(s) of Toxocara canis expand in vitro human $\mathrm{T}$ cells with stable and opposite (type $1 \mathrm{~T}$ helper or type $2 \mathrm{~T}$ helper) profile of cytokine production. J Clin Invest 1991; 88: 346-350.

7. Salgame P, Abrams JS, Clayberger C, et al. Differing lymphokine profiles of functional subsets of human CD4 and CD8 T cell clones. Science 1991; 254: 279282.

8. Maggi E, Giudizi MG, Biagiotti R, et al. Th2-like $\mathrm{CD} 8+\mathrm{T}$ cells showing $\mathrm{B}$ cell helper function and 
reduced cytolytic activity in human immunodeficiency virus type 1 infection. J Exp Med 1994; 180: 489-495.

9. Romagnani S. Induction of $\mathrm{TH} 1$ and $\mathrm{TH} 2$ responses: a key role for the 'natural' immune response? Immunol Today 1992; 13: 379-381.

10. Abbas AK, Murphy KM, Sher A. Functional diversity of helper T lymphocytes. Nature 1996; 383: 787-793.

11. Yabuhara A, Macaubas C, Prescott SL, et al. TH2polarized immunological memory to inhalant allergens in atopics is established during infancy and early childhood. Clin Exp Allergy 1997; 27: 1261-1269.

12. Foster PS, Hogan SP, Ramsay AJ, Matthaei KI, Young IG. Interleukin 5 deficiency abolishes eosinophilia, airways hyperreactivity, and lung damage in a mouse asthma model. J Exp Med 1996; 183: 195-201.

13. Chen Y, Kuchroo VK, Inobe J, Hafler DA, Weiner HL. Regulatory $\mathrm{T}$ cell clones induced by oral tolerance: suppression of autoimmune encephalomyelitis. Science 1994; 265: 1237-1240.

14. Fukaura H, Kent SC, Pietrusewicz MJ, Khoury SJ, Weiner HL, Hafler DA. Induction of circulating myelin basic protein and proteolipid protein-specific transforming growth factor-beta1-secreting Th3 T cells by oral administration of myelin in multiple sclerosis patients. J Clin Invest 1996; 98: 70-77.

15. Bridoux F, Badou A, Saoudi A, et al. Transforming growth factor beta (TGF-beta)-dependent inhibition of T helper cell 2 (Th2)-induced autoimmunity by selfmajor histocompatibility complex (MHC) class IIspecific, regulatory CD4(+) $\mathrm{T}$ cell lines. J Exp Med 1997; 185: 1769-1775.

16. Letterio JJ, Roberts AB. Regulation of immune responses by TGF-beta. Annu Rev Immunol 1998; 16 : $137-161$.

17. Clark DA, Coker R. Transforming growth factor-beta (TGF-beta). Int J Biochem Cell Biol 1998; 30: 293-298.

18. Kehrl JH, Wakefield LM, Roberts AB, et al. Production of transforming growth factor beta by human $\mathrm{T}$ lymphocytes and its potential role in the regulation of T cell growth. $J$ Exp Med 1986; 163: 1037-1050.

19. Barral A, Teixeira M, Reis $\mathrm{P}$, et al. Transforming growth factor-beta in human cutaneous leishmaniasis. Am J Pathol 1995; 147: 947-954.

20. Ahuja SS, Paliogianni F, Yamada H, Balow JE, Boumpas DT. Effect of transforming growth factorbeta on early and late activation events in human T cells. J Immunol 1993; 150: 3109-3118.

21. Espevik T, Waage A, Faxvaag A, Shalaby MR. Regulation of interleukin-2 and interleukin-6 production from T-cells: involvement of interleukin-1 beta and transforming growth factor-beta. Cell Immunol 1990; 126: 47-56.

22. Fargeas $\mathrm{C}, \mathrm{Wu} \mathrm{CY}$, Nakajima T, Cox D, Nutman T, Delespesse G. Differential effect of transforming growth factor beta on the synthesis of Th1- and Th2-like lymphokines by human T lymphocytes. Eur J Immunol 1992; 22: 2173-2176.

23. Espevik T, Figari IS, Shalaby MR, et al. Inhibition of cytokine production by cyclosporin A and transforming growth factor beta. J Exp Med 1987; 166: 571-576.

24. Smyth MJ, Strobl SL, Young HA, Ortaldo JR, Ochoa AC. Regulation of lymphokine-activated killer activity and pore-forming protein gene expression in human peripheral blood CD8+ T lymphocytes. Inhibition by transforming growth factor-beta. J Immunol 1991; 146: 3289-3297.
25. Haneda K, Sano K, Tamura G, Sato T, Habu S, Shirato K. TGF-beta induced by oral tolerance ameliorates experimental tracheal eosinophilia. J Immunol 1997; 159: 4484-4490.

26. Haneda K, Sano K, Tamura G, et al. Transforming growth factor-beta secreted from CD4(+) T cells ameliorates antigen-induced eosinophilic inflammation. A novel high-dose tolerance in the trachea. $\mathrm{Am}$ J Respir Cell Mol Biol 1999; 21: 268-274.

27. Wiedermann U, Jahn-Schmid B, Bohle B, et al. Suppression of antigen-specific T- and B-cell responses by intranasal or oral administration of recombinant bet $\mathrm{v} 1$, the major birch pollen allergen, in a murine model of type I allergy. J Allergy Clin Immunol 1999; 103: $1202-1210$

28. Kopf M, Le Gros G, Bachmann M, Lamers MC, Bluethmann H, Kohler G. Disruption of the murine IL-4 gene blocks Th2 cytokine responses. Nature 1993; 362: 245-248.

29. Bradding P, Feather IH, Howarth $\mathrm{PH}$, et al. Interleukin 4 is localized to and released by human mast cells. J Exp Med 1992; 176: 1381-1386.

30. Brunner T, Heusser CH, Dahinden CA. Human peripheral blood basophils primed by interleukin 3 (IL-3) produce IL-4 in response to immunoglobulin E receptor stimulation. $J$ Exp Med 1993; 177: 605-611.

31. Rissoan MC, Soumelis V, Kadowaki N, et al. Reciprocal control of T helper cell and dendritic cell differentiation. Science 1999; 283: 1183-1186.

32. Kalinski P, Hilkens CM, Wierenga EA, Kapsenberg ML. T-cell priming by type- 1 and type- 2 polarized dendritic cells: the concept of a third signal. Immunol Today 1999; 20: 561-567.

33. Lin H, Mosmann TR, Guilbert L, Tuntipopipat S, Wegmann TG. Synthesis of T helper 2-type cytokines at the maternal-fetal interface. J Immunol 1993; 151: $4562-4573$

34. Szepfalusi Z, Nentwich I, Gerstmayr M, et al. Prenatal allergen contact with milk proteins. Clin Exp Allergy 1997; 27: 28-35.

35. Prescott SL, Macaubas C, Smallacombe T, Holt BJ, Sly PD, Holt PG. Development of allergen-specific T-cell memory in atopic and normal children. Lancet 1999; 353: 196-200.

36. Warner JO, Warner JA, Miles EA, Jones AC. Reduced interferon-gamma secretion in neonates and subsequent atopy. Lancet 1994; 344: 1516.

37. Kondo N, Kobayashi Y, Shinoda S, et al. Reduced interferon gamma production by antigen-stimulated cord blood mononuclear cells is a risk factor of allergic disorders - 6-year follow-up study. Clin Exp Allergy 1998; 28: 1340-1344.

38. Tang ML, Kemp AS, Thorburn J, Hill DJ. Reduced interferon-gamma secretion in neonates and subsequent atopy. Lancet 1994; 344: 983-985.

39. Martinez FD, Stern DA, Wright AL, Holberg CJ, Taussig LM, Halonen M. Association of interleukin-2 and interferon-gamma production by blood mononuclear cells in infancy with parental allergy skin tests and with subsequent development of atopy. J Allergy Clin Immunol 1995; 96: 652-660.

40. Piccinni MP, Beloni L, Giannarini L, et al. Abnormal production of $\mathrm{T}$ helper 2 cytokines interleukin- 4 and interleukin- 5 by $\mathrm{T}$ cells from newborns with atopic parents. Eur J Immunol 1996; 26: 2293-2298.

41. Prescott SL, Macaubas C, Holt BJ, et al. Transplacental priming of the human immune system to 
environmental allergens: universal skewing of initial $\mathrm{T}$ cell responses toward the Th2 cytokine profile. J Immunol 1998; 160: 4730-4737.

42. Herz U, Ahrens B, Scheffold A, Joachim R, Radbruch $\mathrm{A}$, Renz H. Impact of in utero Th2 immunity on T cell deviation and subsequent immediate-type hypersensitivity in the neonate. Eur J Immunol 2000; 30: 714-718.

43. Prescott SL, Sly PD, Holt PG. Raised serum IgE associated with reduced responsiveness to DPT vaccination during infancy. Lancet 1998; 351: 1489.

44. Boros E. Hay fever and asthma during and after jaundice (ascites due to cinchophen poisoning). JAMA 1937; 109: 113 .

45. Gorin N. Temporary relief of asthma by jaundice. JAMA 1949; 141: 24.

46. Mantle J, Pepys J. Asthma amongst Tristan da Cunha islanders. Clin Allergy 1974; 4: 161-170.

47. Tyrrell DA, Peto M, King N. Serological studies on infections by respiratory viruses of the inhabitants of Tristan da Cunha. J Hyg (Lond) 1967; 65: 327-341.

48. Samuels N. Experiences of a medical officer on Tristan da Cunha. BMJ 1961; ii: 1013-1017.

49. Brown P, Gajdusek DC, Morris JA. Epidemic A2 influenza in isolated Pacific island populations without pre-epidemic antibody to influenza virus types $\mathrm{A}$ and $\mathrm{B}$, and the discovery of other still unexposed populations. Am J Epidemiol 1966; 83: 176-188.

50. Brown P, Gajdusek DC. Acute and chronic pulmonary airway disease in Pacific Island Micronesians. Am J Epidemiol 1978; 108: 266-273.

51. Anderson HR. The epidemiological and allergic features of asthma in the New Guinea Highlands. Clin Allergy 1974; 4: 171-183.

52. Flynn MG. Respiratory symptoms, bronchial responsiveness, and atopy in Fijian and Indian children. $\mathrm{Am}$ J Respir Crit Care Med 1994; 150: 415-420.

53. Flynn MG. Respiratory symptoms of rural Fijian and Indian children in Fiji. Thorax 1994; 49: 1201-1204.

54. von Mutius E, Martinez FD, Fritzsch C, Nicolai T, Reitmeir $\mathrm{P}$, Thieman $\mathrm{HH}$. Skin test reactivity and number of siblings. BMJ 1994; 308: 692-695.

55. Serafini U. Long-term asthma remission. Eur J Intern Med 1996; 7: 5-12.

56. Shaheen SO, Aaby P, Hall AJ, et al. Measles and atopy in Guinea-Bissau. Lancet 1996; 347: 1792-1796.

57. Matricardi PM, Rosmini F, Ferrignol L, et al. Cross sectional retrospective study of prevalence of atopy among Italian military students with antibodies against hepatitis A virus. BMJ 1997; 314: 999-1003.

58. Bardin PG, Fraenkel DJ, Sanderson G, Lampe F, Holgate ST. Lower airways inflammatory response during rhinovirus colds. Int Arch Allergy Immunol 1995; 107: 127-129.

59. Shirakawa T, Enomoto T, Shimazu S, Hopkin JM. The inverse association between tuberculin responses and atopic disorder. Science 1997; 275: 77-79.

60. Johnston SL, Pattemore PK, Sanderson G, et al. Community study of role of viral infections in exacerbations of asthma in 9-11 year old children. BMJ 1995; 310: 1225-1229.

61. Nicholson KG, Kent J, Ireland DC. Respiratory viruses and exacerbations of asthma in adults. $B M J$ 1993; 307: 982-986.

62. Calhoun WJ, Swenson CA, Dick EC, Schwartz LB, Lemanske RF, Busse WW. Experimental rhinovirus 16 infection potentiates histamine release after antigen bronchoprovocation in allergic subjects. $A m$ Rev Respir Dis 1991; 144: 1267-1273.

63. Bardin PG, Johnston SL, Pattemore PK. Viruses as precipitants of asthma symptoms. II. Physiology and mechanisms. Clin Exp Allergy 1992; 22: 809-822.

64. Long CE, McBride JT, Hall CB. Sequelae of respiratory syncytial virus infections. A role for intervention studies. Am J Respir Crit Care Med 1995; 151: 1678-1680.

65. Sims DG, Downham MA, Gardner PS, Webb JK, Weightman D. Study of 8-year-old children with a history of respiratory syncytial virus bronchiolitis in infancy. BMJ 1978; 1: 11-14.

66. Pullan CR, Hey EN. Wheezing, asthma, and pulmonary dysfunction 10 years after infection with respiratory syncytial virus in infancy. BMJ (Clin Res Ed) 1982; 284: 1665-1669.

67. Stein RT, Sherrill D, Morgan WJ, et al. Respiratory syncytial virus in early life and risk of wheeze and allergy by age 13 years. Lancet 1999; 354: 541-545.

68. von Mutius E, Illi S, Hirsch T, Leupold W, Keil U, Weiland SK. Frequency of infections and risk of asthma, atopy and airway hyperresponsiveness in children. Eur Respir J 1999; 14: 4-11.

69. Martinez FD, Stern DA, Wright AL, Taussig LM, Halonen M. Association of non-wheezing lower respiratory tract illnesses in early life with persistently diminished serum IgE levels. Group Health Medical Associates. Thorax 1995; 50: 1067-1072.

70. Schwarze J, Hamelmann E, Bradley KL, Takeda K, Gelfand EW. Respiratory syncytial virus infection results in airway hyperresponsiveness and enhanced airway sensitization to allergen. J Clin Invest 1997; 100: 226-233.

71. Teran LM, Johnston SL, Schroder JM, Church MK, Holgate ST. Role of nasal interleukin-8 in neutrophil recruitment and activation in children with virusinduced asthma. Am J Respir Crit Care Med 1997; 155: $1362-1366$.

72. Schwarze J, Gelfand EW. Respiratory viral infections as promoters of allergic sensitization and asthma development: lessons from animal models. Eur Respir $J 2002$ (in press).

73. McIntosh K, Ellis EF, Hoffman LS, Lybass TG, Eller JJ, Fulginiti VA. The association of viral and bacterial respiratory infections with exacerbations of wheezing in young asthmatic children. $J$ Pediatr 1973; 82: 578590.

74. Slavin RG. Asthma and sinusitis. $J$ Allergy Clin Immunol 1992; 90: 534-537.

75. Cypcar D, Stark J, Lemanske RF Jr. The impact of respiratory infections on asthma. Pediatr Clin North Am 1992; 39: 1259-1276.

76. Friedman R, Ackerman M, Wald E, Casselbrant M, Friday G, Fireman P. Asthma and bacterial sinusitis in children. J Allergy Clin Immunol 1984; 74: 185-189.

77. Rachelefsky GS, Katz RM, Siegel SC. Chronic sinus disease with associated reactive airway disease in children. Pediatrics 1984; 73: 526-529.

78. Allegra L, Blasi F, Centanni S, et al. Acute exacerbations of asthma in adults: role of Chlamydia pneumoniae infection. Eur Respir J 1994; 7: 2165-2168.

79. Mills KH, Barnard A, Watkins J, Redhead K. Cellmediated immunity to Bordetella pertussis: role of Th1 cells in bacterial clearance in a murine respiratory infection model. Infect Immunol 1993; 61: 399-410.

80. Yeung VP, Gieni RS, Umetsu DT, DeKruyff RH. 
Heat-killed Listeria monocytogenes as an adjuvant converts established murine Th2-dominated immune responses into Th1-dominated responses. J Immunol 1998; 161: 4146-4152.

81. Scharton TM, Scott P. Natural killer cells are a source of interferon gamma that drives differentiation of CD4+ $\mathrm{T}$ cell subsets and induces early resistance to Leishmania major in mice. J Exp Med 1993; 178: 567577.

82. Schlaak JF, Nieder P, Meyer zum Buschenfelde KH, Fleischer B. Human $\mathrm{T}$ helper cells reactive with somatic bacterial antigens belong to the Th1 subset. Med Microbiol Immunol (Berl) 1994; 183: 169-175.

83. Alm JS, Lilja G, Pershagen G, Scheynius A. Early BCG vaccination and development of atopy. Lancet 1997; 350: 400-403.

84. Alm JS, Lilja G, Pershagen G, Scheynius A. BCG vaccination does not seem to prevent atopy in children with atopic heredity. Allergy 1998; 53: 537.

85. Aaby P, Shaheen SO, Heyes CB, et al. Early BCG vaccination and reduction in atopy in guinea-bissau. Clin Exp Allergy 2000; 30: 644-650.

86. Strannegard IL, Larsson LO, Wennergren G, Strannegard O. Prevalence of allergy in children in relation to prior BCG vaccination and infection with atypical mycobacteria. Allergy 1998; 53: 249-254.

87. von Mutius E, Pearce N, Beasley R, et al. International patterns of tuberculosis and the prevalence of symptoms of asthma, rhinitis, and eczema. Thorax 2000; 55: 449-453.

88. Herz U, Gerhold K, Gruber C, et al. BCG infection suppresses allergic sensitization and development of increased airway reactivity in an animal model. J Allergy Clin Immunol 1998; 102: 867-874.

89. Erb KJ, Holloway JW, Sobeck A, Moll H, Le Gros G. Infection of mice with Mycobacterium bovis-Bacillus Calmette-Guerin (BCG) suppresses allergen-induced airway eosinophilia. J Exp Med 1998; 187: 561-569.

90. Wang CC, Rook GA. Inhibition of an established allergic response to ovalbumin in BALB/c mice by killed Mycobacterium vaccae. Immunology 1998; 93: 307-313.

91. Murosaki S, Yamamoto Y, Ito K, et al. Heat-killed Lactobacillus plantarum L-137 suppresses naturally fed antigen-specific IgE production by stimulation of IL-12 production in mice. J Allergy Clin Immunol 1998; 102: 57-64.

92. Lipford GB, Bauer M, Blank C, Reiter R, Wagner H, Heeg K. CpG-containing synthetic oligonucleotides promote $\mathrm{B}$ and cytotoxic $\mathrm{T}$ cell responses to protein antigen: a new class of vaccine adjuvants. Eur J Immunol 1997; 27: 2340-2344.

93. Chu RS, Targoni OS, Krieg AM, Lehmann PV, Harding CV. CpG oligodeoxynucleotides act as adjuvants that switch on T helper 1 (Th1) immunity. J Exp Med 1997; 186: 1623-1631.

94. Sun S, Kishimoto H, Sprent J. DNA as an adjuvant: capacity of insect DNA and synthetic oligodeoxynucleotides to augment $\mathrm{T}$ cell responses to specific antigen. J Exp Med 1998; 187: 1145-1150.

95. Davis HL, Weeratna R, Waldschmidt TJ, et al. CpG DNA is a potent enhancer of specific immunity in mice immunized with recombinant hepatitis B surface antigen. J Immunol 1998; 160: 870-876.

96. Raz E, Tighe H, Sato Y, et al. Preferential induction of a Th1 immune response and inhibition of specific
IgE antibody formation by plasmid DNA immunization. Proc Natl Acad Sci USA 1996; 93: 5141-5145.

97. Hartl A, Kiesslich J, Weiss R, et al. Immune responses after immunization with plasmid DNA encoding Bet $\mathrm{v} 1$, the major allergen of birch pollen. J Allergy Clin Immunol 1999; 103: 107-113.

98. Hsu CH, Chua KY, Tao MH, et al. Immunoprophylaxis of allergen-induced immunoglobulin $\mathrm{E}$ synthesis and airway hyperresponsiveness in vivo by genetic immunization. Nat Med 1996; 2: 540-544.

99. Broide D, Schwarze J, Tighe H, et al. Immunostimulatory DNA sequences inhibit IL-5, eosinophilic inflammation, and airway hyperresponsiveness in mice. J Immunol 1998; 161: 7054-7062.

100. Yamamoto S, Yamamoto T, Shimada S, et al. DNA from bacteria, but not from vertebrates, induces interferons, activates natural killer cells and inhibits tumor growth. Microbiol Immunol 1992; 36: 983-997.

101. Spiegelberg HL, Orozco EM, Roman M, Raz E. DNA immunization: a novel approach to allergen-specific immunotherapy. Allergy 1997; 52: 964-970.

102. Sato $\mathrm{Y}$, Roman $\mathrm{M}$, Tighe $\mathrm{H}$, et al. Immunostimulatory DNA sequences necessary for effective intradermal gene immunization. Science 1996; 273: 352-354.

103. Krieg AM, Love-Homan L, Yi AK, Harty JT. CpG DNA induces sustained IL-12 expression in vivo and resistance to Listeria monocytogenes challenge. J Immunol 1998; 161: 2428-2434.

104. Krieg AM, Yi AK, Matson S, et al. CpG motifs in bacterial DNA trigger direct B-cell activation. Nature 1995; 374: 546-549.

105. Klinman DM, Yi AK, Beaucage SL, Conover J, Krieg AM. CpG motifs present in bacteria DNA rapidly induce lymphocytes to secrete interleukin 6, interleukin 12, and interferon gamma. Proc Natl Acad Sci USA 1996; 93: 2879-2883.

106. Roman M, Martin-Orozco E, Goodman JS, et al. Immunostimulatory DNA sequences function as $\mathrm{T}$ helper-1-promoting adjuvants. Nat Med 1997; 3: 849854.

107. Tokunaga T, Yamamoto H, Shimada S, et al. Antitumor activity of deoxyribonucleic acid fraction from Mycobacterium bovis BCG. I. Isolation, physicochemical characterization, and antitumor activity. $J$ Natl Cancer Inst 1984; 72: 955-962.

108. Field AK, Tytell AA, Lampson GP, Hilleman MR. Inducers of interferon and host resistance. II. Multistranded synthetic polynucleotide complexes. Proc Natl Acad Sci USA 1967; 58: 1004-1010.

109. Lampson GP, Tytell AA, Field AK, Nemes MM, Hilleman MR. Inducers of interferon and host resistance. I. Double-stranded RNA from extracts of Penicillium funiculosum. Proc Natl Acad Sci USA 1967; 58: 782-789.

110. Zilberstein A, Kimchi A, Schmidt A, Revel M. Isolation of two interferon-induced translational inhibitors: a protein kinase and an oligo-isoadenylate synthetase. Proc Natl Acad Sci USA 1978; 75: 4734 4738.

111. Meurs E, Chong K, Galabru J, et al. Molecular cloning and characterization of the human doublestranded RNA-activated protein kinase induced by interferon. Cell 1990; 62: 379-390.

112. Broide D, Raz E. DNA-based immunization for asthma. Int Arch Allergy Immunol 1999; 118: 453456.

113. Kline JN, Waldschmidt $\mathrm{TJ}$, Businga TR, et al. 
Modulation of airway inflammation by $\mathrm{CpG}$ oligodeoxynucleotides in a murine model of asthma. J Immunol 1998; 160: 2555-2559.

114. Sur S, Wild JS, Choudhury BK, Sur N, Alam R, Klinman DM. Long term prevention of allergic lung inflammation in a mouse model of asthma by $\mathrm{CpG}$ oligodeoxynucleotides. J Immunol 1999; 162: 6284 6293.

115. Bohle B, Jahn-Schmid B, Maurer D, Kraft D, Ebner C. Oligodeoxynucleotides containing $\mathrm{CpG}$ motifs induce IL-12, IL-18 and IFN-gamma production in cells from allergic individuals and inhibit IgE synthesis in vitro. Eur J Immunol 1999; 29: 2344-2353.

116. Svanes C, Jarvis D, Chinn S, Burney P. Childhood environment and adult atopy: results from the European Community Respiratory Health Survey. J Allergy Clin Immunol 1999; 103: 415-420.

117. Matricardi PM, Franzinelli F, Franco A, et al. Sibship size, birth order, and atopy in 11,371 Italian young men. J Allergy Clin Immunol 1998; 101: 439-444.

118. Kramer U, Heinrich J, Wjst M, Wichmann HE. Age of entry to day nursery and allergy in later childhood. Lancet 1999; 353: 450-454.

119. Lau S, Illi S, Sommerfeld C, et al. Early exposure to house-dust mite and cat allergens and development of childhood asthma: a cohort study. Multicentre Allergy Study Group. Lancet 2000; 356: 1392-1397.

120. Illi S, von Mutius E, Lau S, et al. Early childhood infectious diseases and the development of asthma up to school age: a birth cohort study. BMJ 2001; 322: 390-395.

121. Braun-Fahrlander C, Gassner M, Grize L, et al. Prevalence of hay fever and allergic sensitization in farmer's children and their peers living in the same rural community. SCARPOL team. Swiss Study on Childhood Allergy and Respiratory Symptoms with Respect to Air Pollution. Clin Exp Allergy 1999; 29: 28-34.

122. Von Ehrenstein OS, Von Mutius E, Illi S, Baumann L, Bohm O, von Kries R. Reduced risk of hay fever and asthma among children of farmers. Clin Exp Allergy 2000; 30: 187-193.

123. Riedler J, Eder W, Oberfeld G, Schreuer M. Austrian children living on a farm have less hay fever, asthma and allergic sensitization. Clin Exp Allergy 2000; 30: 194-200.

124. Rylander R, Haglind P, Lundholm M. Endotoxin in cotton dust and respiratory function decrement among cotton workers in an experimental cardroom. Am Rev Respir Dis 1985; 131: 209-213.

125. Donham K, Haglind P, Peterson Y, Rylander R, Belin L. Environmental and health studies of farm workers in Swedish swine confinement buildings. $\mathrm{Br} J$ Ind Med 1989; 46: 31-37.

126. Gereda JE, Leung DYM, Thatayatikom A, et al. Relation between house-dust endotoxin exposure, type 1 T-cell development, and allergen sensitisation in infants at high risk of asthma. Lancet 2000; 355: 1680 1683.

127. Park JH, Gold DR, Spiegelman DL, Burge HA, Milton DK. House dust endotoxin and wheeze in the first year of life. Am J Respir Crit Care Med 2001; 163 : 322-328.

128. Baldini M, Lohman IC, Halonen M, Erickson RP, Holt PG, Martinez FD. A Polymorphism* in the 5' flanking region of the CD14 gene is associated with circulating soluble CD14 levels and with total serum immunoglobulin E. Am J Respir Cell Mol Biol 1999; 20: 976-983.

129. Bjorksten B, Naaber P, Sepp E, Mikelsaar M. The intestinal microflora in allergic Estonian and Swedish 2-year-old children. Clin Exp Allergy 1999; 29: 342346.

130. Vannier E, Lefort J, Lellouch-Tubiana A, Terlain B, Vargaftig BB. Lipopolysaccharide from Escherichia coli reduces antigen-induced bronchoconstriction in actively sensitized guinea pigs. J Clin Invest 1991; 87: 1936-1944.

131. Tulic MK, Wale JL, Holt PG, Sly PD. Modification of the inflammatory response to allergen challenge after exposure to bacterial lipopolysaccharide. Am J Respir Cell Mol Biol 2000; 22: 604-612.

132. Slater JE, Paupore EJ, Elwell MR, Truscott W. Lipopolysaccharide augments $\mathrm{IgG}$ and $\mathrm{IgE}$ responses of mice to the latex allergen Hev b 5. J Allergy Clin Immunol 1998; 102: 977-983.

133. Dubin W, Martin TR, Swoveland P, et al. Asthma and endotoxin: lipopolysaccharide-binding protein and soluble CD14 in bronchoalveolar compartment. Am J Physiol 1996; 270: L736-L744.

134. Bunikowski R, Mielke M, Skarabis H, et al. Prevalence and role of serum IgE antibodies to the Staphylococcus aureus-derived superantigens SEA and SEB in children with atopic dermatitis. J Allergy Clin Immunol 1999; 103: 119-124.

135. Bunikowski R, Mielke ME, Skarabis $\mathrm{H}$, et al. Evidence for a disease-promoting effect of Staphylococcus aureus-derived exotoxins in atopic dermatitis. J Allergy Clin Immunol 2000; 105: 814-819.

136. Strickland I, Hauk PJ, Trumble AE, Picker LJ, Leung DY. Evidence for superantigen involvement in skin homing of $\mathrm{T}$ cells in atopic dermatitis. $J$ Invest Dermatol 1999; 112: 249-253.

137. Herz U, Schnoy N, Borelli S, et al. A human-SCID mouse model for allergic immune response bacterial superantigen enhances skin inflammation and suppresses IgE production. J Invest Dermatol 1998; 110: 224-231.

138. Skov L, Olsen JV, Giorno R, Schlievert PM, Baadsgaard O, Leung DY. Application of Staphylococcal enterotoxin $\mathrm{B}$ on normal and atopic skin induces up-regulation of $\mathrm{T}$ cells by a superantigenmediated mechanism. J Allergy Clin Immunol 2000; 105: 820-826.

139. Breuer K, Wittmann M, Bosche B, Kapp A, Werfel T. Severe atopic dermatitis is associated with sensitization to staphylococcal enterotoxin B (SEB). Allergy 2000; 55: 551-555.

140. Saloga J, Lack G, Bradley K, et al. Inhibition of the development of immediate hypersensitivity by staphylococcal enterotoxin B. Eur J Immunol 1994; 24: 3140 3147. 